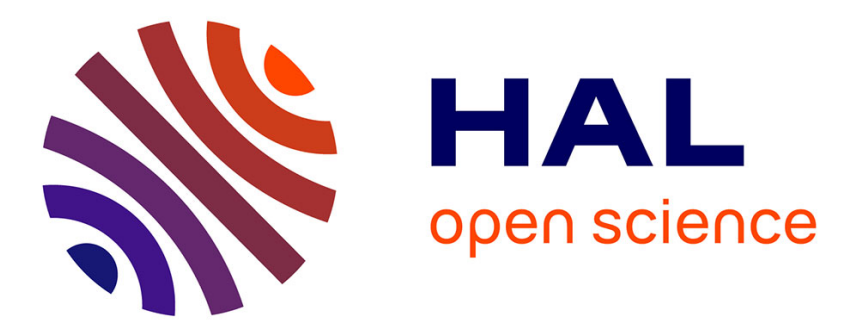

\title{
J-RESISTANCE CURVES FROM INTERRUPTED IMPACT TESTS
}

\author{
C. Marschall, P. Held
}

\section{To cite this version:}

C. Marschall, P. Held. J-RESISTANCE CURVES FROM INTERRUPTED IMPACT TESTS. Journal de Physique Colloques, 1985, 46 (C5), pp.C5-239-C5-244. 10.1051/jphyscol:1985531 . jpa-00224761

\section{HAL Id: jpa-00224761 https://hal.science/jpa-00224761}

Submitted on 1 Jan 1985

HAL is a multi-disciplinary open access archive for the deposit and dissemination of scientific research documents, whether they are published or not. The documents may come from teaching and research institutions in France or abroad, or from public or private research centers.
L'archive ouverte pluridisciplinaire HAL, est destinée au dépôt et à la diffusion de documents scientifiques de niveau recherche, publiés ou non, émanant des établissements d'enseignement et de recherche français ou étrangers, des laboratoires publics ou privés. 
JOURNAL DE PHYSIQUE

Colloque C5, supplément au n8, Tome 46, août 1985

page $\mathrm{C} 5-239$

\title{
J-RESISTANCE CURVES FROM INTERRUPTED IMPACT TESTS
}

\author{
C.W. Marschall and P.R. Held \\ Battelle, Columbus Laboratories, 505 King Avenue, Columbus, Ohio 43201-2693, \\ U.S.A.
}

Résumé - Une méthode pour la dëtermination des courbes de résistance à la propagation de fissure J.sa pour des vitesses de déplacement de 1 à 2 mẽtres par seconde est proposée.

Abstract - A method is described for determining J-resistance curves at displacement rates of 1 to 2 meters per second.

\section{I - INTRODUCTION}

An increasingly common method for characterizing a material's resistance to stable crack propagation is the 3 -resistance curve $/ 1 /$. Such a curve can be calculated from tests conducted on standard fracture-mechanics specimens, principally compacttype specimens and 3-point bend specimens. The data necessary to calculate a J-resistance curve include force and crack length as a function of loading-point displacement. Typically, tests to develop J-resistance curves are conducted quasistatically, thus permitting crack growth to be measured by one of several accepted methods, including an unloading-compliance technique /2/ and an electricpotential technique $/ 3 /$.

The need for developing J-resistance curves for high rates of loading came about in connection with a problem encouritered in boiling-water reactors. There was concern that stress-corrosion cracks that have been observed in Type 304 austenitic stainless steel coolant pipes after prolonged service might lead to sudden and complete rupture of the pipe in the face of transient overloads, such as might be associated with an earthquake or accident.

This paper describes a relatively simple and straightforward method for determining J-resistance curves at high rates of loading.

\section{II - EXPERIMENTAL METHODS}

The method that was developed for obtaining J-resistance curves at high rates of loading employed a notched 3-point bend specimen and a dropweight tower. The bend specimen is shown in Figure 1. Two different specimen thicknesses were studied to simulate two sizes of pipes used in boiling water reactors. A sharp notch was introduced at midspan by electric-discharge machining. However, a fatigue precrack could have been used equally well.

The dropweight tower is illustrated schematically in Figure 2. It was located at the Fracture Control Corporation in Goleta, Cal ifornia, U.S.A. It contained a striker instrumented with semiconductor strain-gages to permit measurement of force variation with time as the specimen was deflected by the striker. The force/time signal was captured and preserved for later analysis by means of a transient recorder, an oscilloscope, and a hardcopy plotter. Weights of up to $10 \mathrm{kN}$ and 


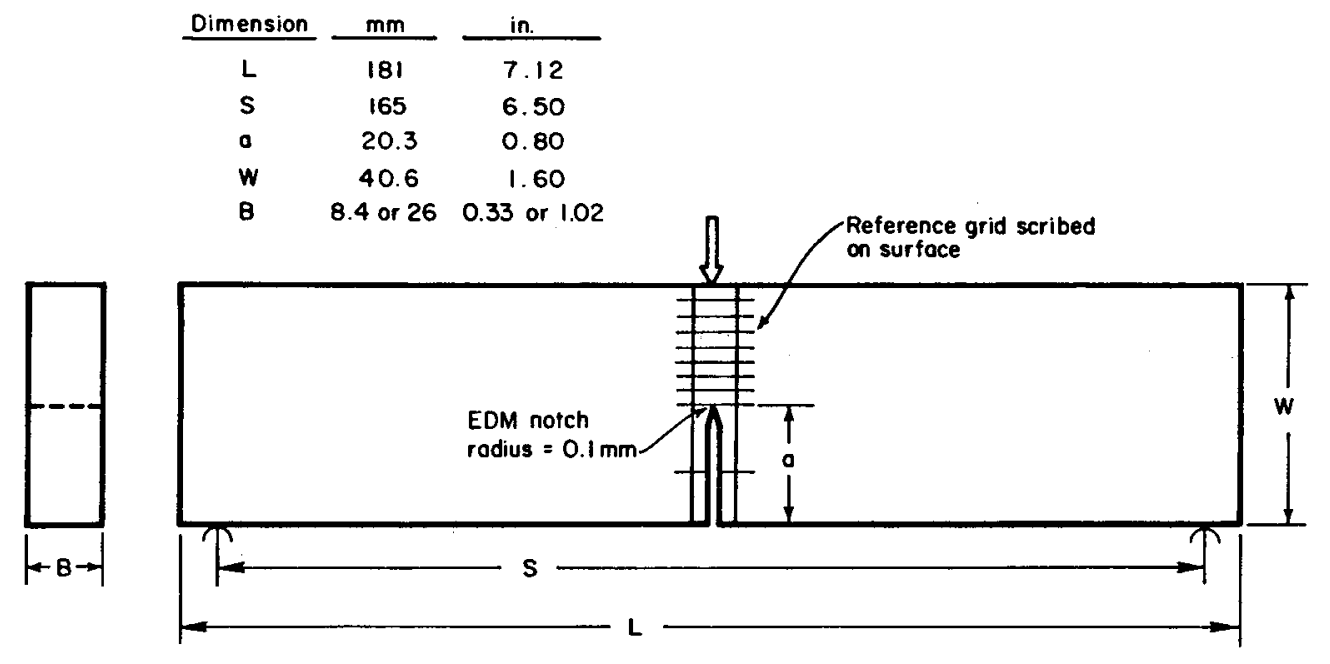

FIGURE 1. NOTCHED THREE-POINT-BEND SPECIMEN

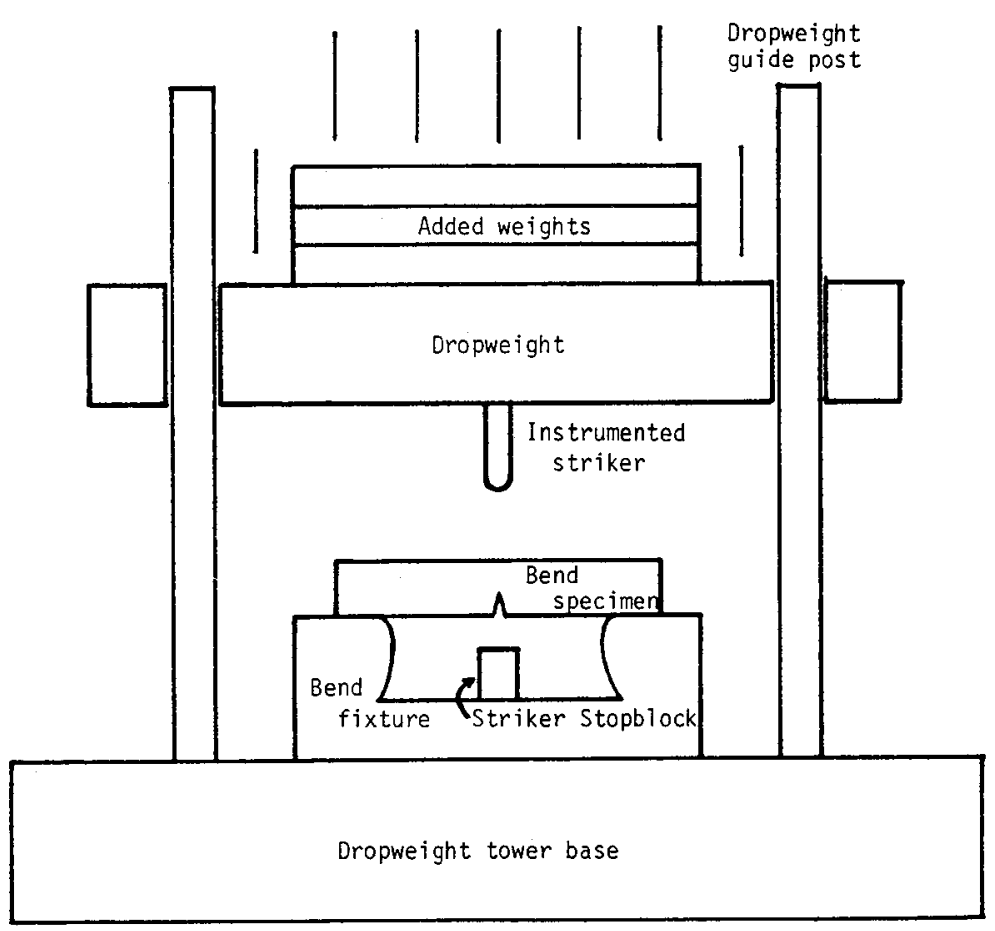

FIGURE 2. SCHEMATIC ILLUSTRATION OF DROPWEIGHT TOWER FOR IMPACT LOADING OF 3-POINT BEND SPECIMEN 
dropheights of up to $1.8 \mathrm{~m}$ were available. The tower also contained an optical velocimeter that measured the striker velocity immediately prior to contact with the specimen.

To simplify the experiments, it was decided not to attempt to measure loading point displacement and crack extension in real time as an individual specimen was deflected under impact loading. Instead, it was decided to employ a multiple specimen method in which 8 to 10 nominally identical specimens were subjected to an interrupted impact test, i.e., the instrumented striker was stopped abruptly after imparting a predetermined amount of deflection to the specimen. The striker was stopped by a hardened-steel stopblock of adjustable height located on one side of the specimen. By selecting a wide range of deflections, individual specimens could be caused to show smal1, intermediate, or large amounts of crack growth. For each specimen tested, the value of force, load-point displacement, and crack length existing at the time of stopping the falling weight could be determined easily and could then be combined to form a composite graph of force and crack length versus load-point displacement. The force value was obtained from the force/time record at a point immediately prior to the appearance of a sharp spike, caused by the rapid deceleration of the striker (see Figure 3 ). The remaining quantities needed--load-point displacement and crack length--were determined from measurements made directly on the specimens after their removal from the impact device. Final crack length was measured on the tested specimen after it was heat tinted to mark the crack front and then broken open to reveal the fracture surface.

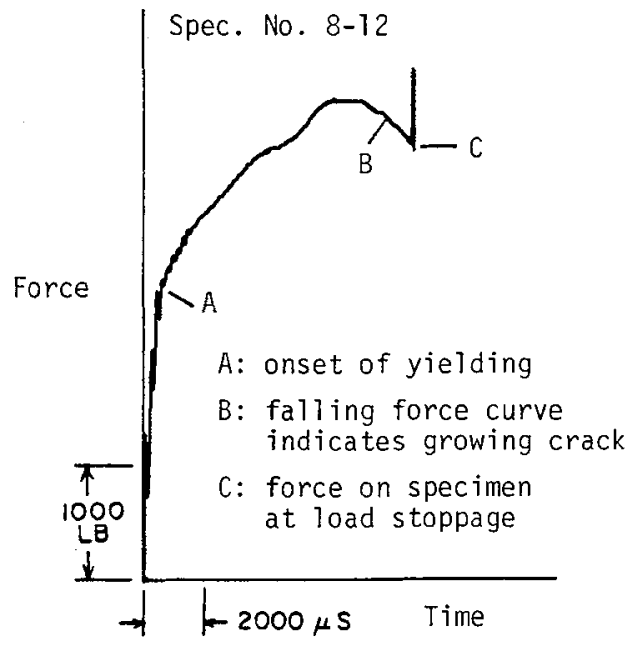

FIGURE 3. LOAD-VERSUS-TIME CURVE FOR INTERRUPTED IMPACT TEST

In selecting weights and dropheights for interrupted impact experiments, it is desirable that the energy available in the falling weight exceed by a significant amount that absorbed by the specimen. If not, the displacement rate will be lowered appreciably as the specimen deforms. On the other hand, if the kinetic energy is greatly excessive, damage to the instrumented striker or to the stopblock may occur when the falijing weight stops abruptly. In the tests described here, actual weights used were about $5 \mathrm{kN}$ and $9.4 \mathrm{kN}$ for the $8.4 \mathrm{~mm}$ and $26 \mathrm{~mm}$ specimens, respectively. Drop heights ranged from 50 to $250 \mathrm{~mm}$, depending on the planned amount of specimen deflection. The resulting initial displacement rates were in the range from about 1 to $2 \mathrm{~m} / \mathrm{s}$. This rate is about 5 orders of magnitude greater than that typically employed in quasistatic bend tests. Some slowing of the striker was observed but was not considered to significantly affect the 
results. The ratio of striker final velocity, $V_{2}$, to initial velocity, $V_{1}$, can be estimated from the ratio of energy absorbed, $U_{A}$, to the energy available initially, $U_{0}$ :

$$
v_{2} / v_{1}=\left(1-U_{A} / U_{0}\right)^{1 / 2}
$$

For the $8.4 \mathrm{~mm}$ specimens, $V_{2} / V_{1}$ ranged from about 0.8 to 0.9 , whereas for $26 \mathrm{~mm}$ specimens, the ratio ranged from about 0.5 to 0.9 . The smallest value calculated for $V_{2}$ was about $0.8 \mathrm{~m} / \mathrm{s}$. Based on experience with many metallic materials, a change in strain rate by a factor of 2 or less during the course of a test is unlikely to have a significant effect.

\section{III - RESULTS}

Examples of data obtained in the manner herein described are presented in Table 7 and Figure 4 for $8.4 \mathrm{~mm}$ and $26 \mathrm{~mm}$ Type 304 stainless steel plates. Each data point in the graphs represents an individual interrupted impact test. A smooth curve has been fitted through the data points and, for the $P-\delta$ curve, a point corresponding to the onset of plastic yielding (see Figure 3 ). The dashed curves represent the degree of scatter observed in the $\mathrm{P}-\delta$ curve among all the specimens tested.

With data such as are shown in Table 1 and Figure 4 , it is a simple matter to calculate $J$ as a function of $\Delta a$, i.e., the J-resistance curve. Figure 5 shows such curves for the two specimen-thicknesses employed in obtaining Figure 4 . In Figure 5, J was calculated from an expression specified in ASTM E813-81, Standard Method for $\mathrm{J}_{I c}$, a Measure of Fracture Toughness. However, the curves in Figure 5 should be viewed only as examples because the recommended expressions for calculating $J$ are in the process of being altered.

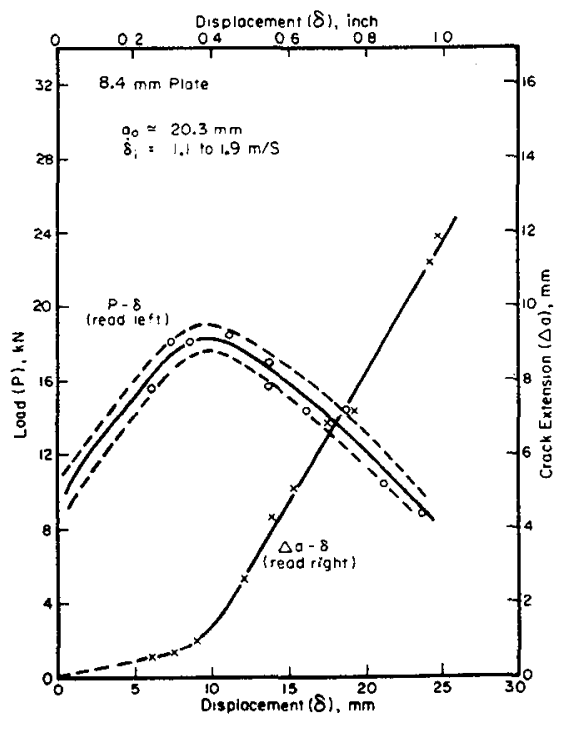

(a) 8.4-mm-thick

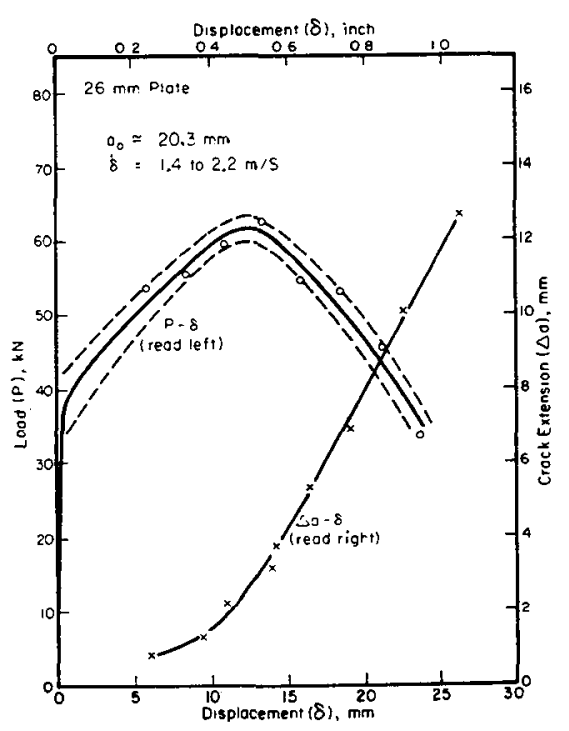

(b) $26-\mathrm{mm}$ thick

FIGURE 4. RESULTS OF INTERRUPTED IMPACT TESTS ON SHARP-NOTCHED 3-POINT BEND SPECIMENS 
TABLE 1. RESULTS OF INTERRUPTED IMPACT TESTS ON TYPE 304 STAINLESS STEEL SHARP-NOTCH BEND SPECIMENS

$$
W=40.64 \mathrm{~mm} \quad a_{0} / W \simeq 0.5 \quad \text { Notch root radius }=0.1 \pm 0.025 \mathrm{~mm}
$$

\begin{tabular}{|c|c|c|c|c|c|c|c|c|c|}
\hline $\begin{array}{l}\text { Speci- } \\
\text { men } \\
\text { No. }\end{array}$ & $\begin{array}{c}\text { Initial } \\
\text { Striker } \\
\text { velocity, } \\
\mathrm{m} / \mathrm{s}\end{array}$ & $\begin{array}{l}\text { Approx. } \\
\text { Pyield, } \\
\text { kN }\end{array}$ & $P_{k N}$ & $\mathrm{P}_{\mathrm{SB}}{ }_{\mathrm{kN}}$ & ${ }_{\mathrm{SB}}^{\delta_{\mathrm{mm}}}{ }^{(a)}$ & $\delta_{f},(b)$ & $\begin{array}{c}a_{0}, \\
\mathrm{~mm}\end{array}$ & $\begin{array}{l}\Delta \mathrm{a}, \\
\mathrm{mm}\end{array}$ & $\underset{\mathrm{mm}}{\mathrm{COO}}(\mathrm{c})$ \\
\hline \multicolumn{10}{|c|}{ 8.4-mm-thick } \\
\hline $\begin{array}{l}8-11 \\
8-15 \\
8-6 \\
8-16 \\
8-2\end{array}$ & $\begin{array}{l}1.33 \\
1.34 \\
1.39 \\
1.47 \\
1.13\end{array}$ & $\begin{array}{r}10.7 \\
10.2 \\
10.7 \\
10.7 \\
9.3\end{array}$ & $\begin{array}{l}\text { (d) } \\
\text { (d) } \\
\text { (d) } \\
\text { (d) } \\
17.5\end{array}$ & $\begin{array}{l}15.50 \\
18.10 \\
18.10 \\
18.40 \\
15.60\end{array}$ & $\begin{array}{r}5.97 \\
7.24 \\
8.51 \\
11.10 \\
13.60\end{array}$ & $\begin{array}{r}6.02 \\
7.47 \\
8.86 \\
12.00 \\
13.80\end{array}$ & $\begin{array}{l}20.27 \\
20.02 \\
20.24 \\
20.27 \\
20.07\end{array}$ & $\begin{array}{l}0.51 \\
0.66 \\
0.94 \\
2.62 \\
4.29\end{array}$ & $\begin{array}{l}1.09 \\
1.27 \\
1.52 \\
2.36 \\
3.40\end{array}$ \\
\hline $\begin{array}{l}8-12 \\
8-9 \\
8-10 \\
8-17 \\
8-4\end{array}$ & $\begin{array}{l}1.57 \\
1.75 \\
1.74 \\
1.86 \\
2.01\end{array}$ & $\begin{array}{l}10.2 \\
11.1 \\
11.1 \\
11.1 \\
11.6\end{array}$ & $\begin{array}{l}18.6 \\
18.1 \\
18.9 \\
18.0 \\
18.4\end{array}$ & $\begin{array}{r}16.90 \\
14.40 \\
14.40 \\
10.50 \\
8.79\end{array}$ & $\begin{array}{l}13.60 \\
16.10 \\
18.70 \\
21.20 \\
23.70\end{array}$ & $\begin{array}{l}15.10 \\
17.50 \\
19.20 \\
24.10 \\
24.80\end{array}$ & $\begin{array}{l}20.02 \\
20.35 \\
20.02 \\
20.19 \\
20.29\end{array}$ & $\begin{array}{r}5.11 \\
6.86 \\
7.19 \\
11.20 \\
11.90\end{array}$ & $\begin{array}{l}3.35 \\
4.55 \\
4.93 \\
7.29 \\
7.82\end{array}$ \\
\hline \multicolumn{10}{|c|}{ 26-mm-thick } \\
\hline $\begin{array}{l}25-17 \\
25-15 \\
25-8 \\
25-12 \\
25-19\end{array}$ & $\begin{array}{l}1.39 \\
1.47 \\
1.54 \\
1.59 \\
1.63\end{array}$ & $\begin{array}{l}32.0 \\
32.9 \\
32.9 \\
35.6 \\
35.6\end{array}$ & $\begin{array}{r}(d) \\
(d) \\
59.2 \\
63.6 \\
62.3\end{array}$ & $\begin{array}{l}53.4 \\
55.6 \\
59.6 \\
62.7 \\
61.4\end{array}$ & $\begin{array}{r}5.97 \\
8.51 \\
11.00 \\
13.60 \\
13.60\end{array}$ & $\begin{array}{r}5.97 \\
9.32 \\
11.00 \\
14.00 \\
14.20\end{array}$ & $\begin{array}{l}20.02 \\
20.07 \\
20.27 \\
20.02 \\
19.99\end{array}$ & $\begin{array}{l}0.81 \\
1.27 \\
2.21 \\
3.75 \\
3.78\end{array}$ & $\begin{array}{l}0.69 \\
1.50 \\
2.13 \\
2.79 \\
2.87\end{array}$ \\
\hline $\begin{array}{l}25-10 \\
25-11 \\
25-7 \\
25-13\end{array}$ & $\begin{array}{l}1.74 \\
1.77 \\
1.93 \\
2.12\end{array}$ & $\begin{array}{l}34.7 \\
35.2 \\
36.9 \\
37.8\end{array}$ & $\begin{array}{l}59.6 \\
61.0 \\
62.7 \\
62.7\end{array}$ & $\begin{array}{l}54.7 \\
53.0 \\
45.4 \\
33.8\end{array}$ & $\begin{array}{l}16.10 \\
18.70 \\
21.20 \\
23.70\end{array}$ & $\begin{array}{l}16.50 \\
19.10 \\
22.70 \\
26.50\end{array}$ & $\begin{array}{l}20.24 \\
20.24 \\
19.94 \\
20.04\end{array}$ & $\begin{array}{r}5.36 \\
6.91 \\
10.70 \\
12.70\end{array}$ & $\begin{array}{l}3.78 \\
4.67 \\
5.97 \\
7.19\end{array}$ \\
\hline
\end{tabular}
(a) Measured at moment of striker contact with stopblock.
(b) Measured after completion of test.
(c) Displacement at original notch tip measured between points located $3.18 \mathrm{~mm}$ on either side of crack
(d) Test was interrupted prior to reaching maximum load in the load/time record. 


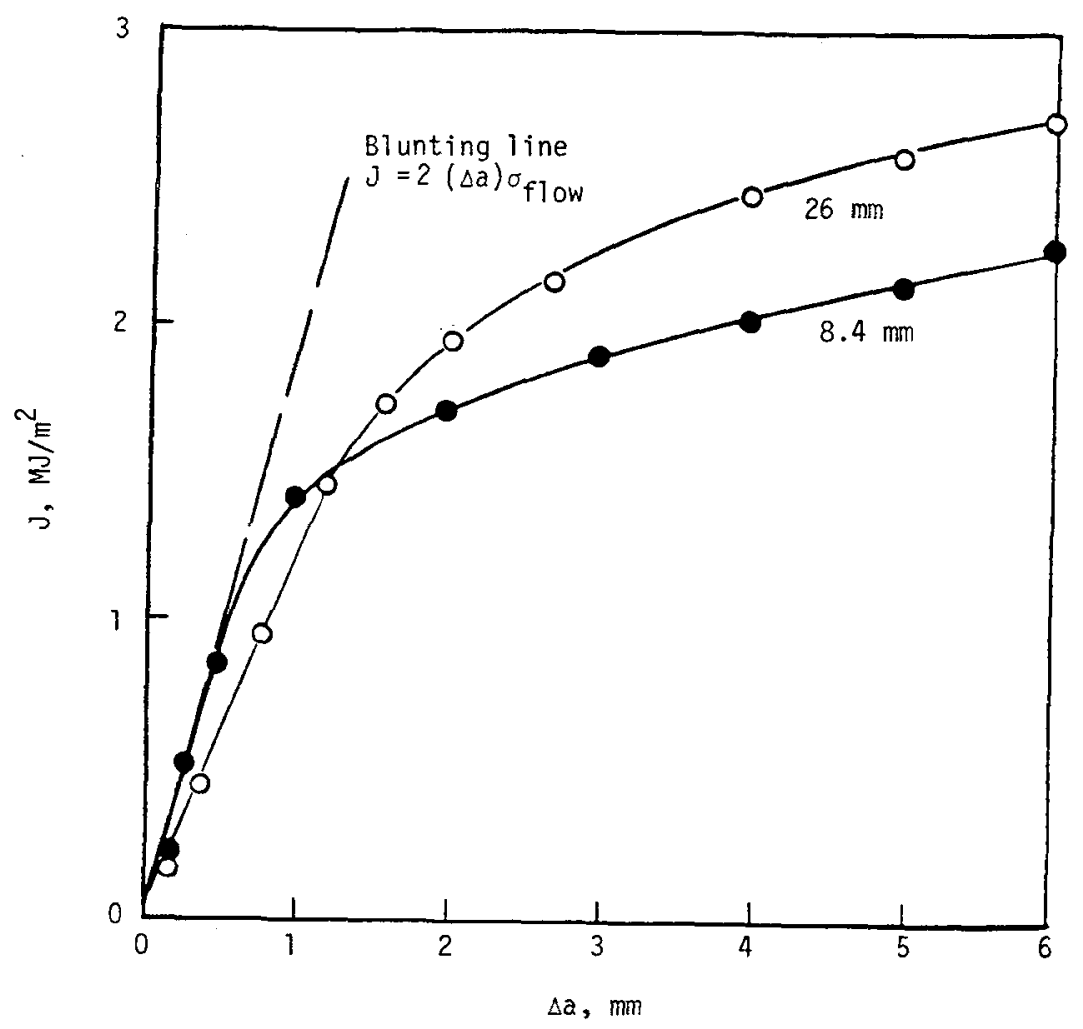

FIGURE 5. J-RESISTANCE CURVES FOR ANNEALED TYPE 304 STAINLESS STEEL OBTAINED FROM INTERRUPTED IMPACT TESTS

\section{IV - ACKNOWLEDGEMENTS}

The authors acknowledge the invaluable assistance of Paul McConnell and William Sheckerd of the Fracture Control Corporation in Goleta, California, USA, in conducting the interrupted impact tests. Appreciation is expressed al so to Dr. Robin Jones and Dr. Douglas Norris of the Electric Power Research Institute for their support of this work (EPRI Research Project T118-2) that pertained to instability predictions for circumferentially cracked Type 304 stainless steel pipes under dynamic loading.

\section{REFERENCES}

11/ McCabe, D. E., Landes, J. D., and Ernst, H. A., Elastic-Plastic Fracture: Second Sysmposium, Volume II--Fracture Resistance Curves and Engineering Applications, ASTM STP 803, American Society for Testing and Materials (1983) II-562.

12/ Clarke, G. A., Andrews, W. R., Paris, P. C., and Schmidt, D. W., Mechanics of Crack Growth, ASTM STP 590, American Society for Testing and Materials (1976) 27.

13/ Schwalbe, K.-H., and Hellman, D., J. Testing and Evaluation, 9, No. 3 (1981) 218. 